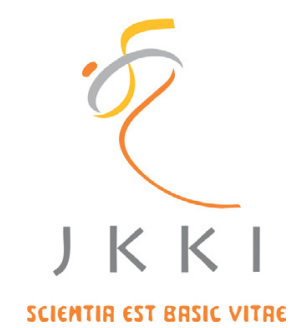

Jurnal Kedokteran dan Kesehatan Indonesia

Indonesian Journal of Medicine and Health

Journal homepage : https://journal.uii.ac.id//KKI/index

\title{
Difference of changes in total and triglyseride cholesterol levels of insulin monotherapy use with combination insulin and metformin therapy in type II diabetes mellitus patients
}

\author{
Prita Murani Nugraheti*1, Erlina Marfianti ${ }^{2}$ Linda Rosita $^{3}$ \\ ${ }^{1}$ Undergraduate Student, Faculty of Medicine, Universitas Islam Indonesia, Yogyakarta, Indonesia \\ ${ }^{2}$ Department of Internal Medicine, Faculty of Medicine, Universitas Islam Indonesia, Yogyakarta, Indonesia \\ ${ }^{3}$ Department of Clinical Pathology, Faculty of Medicine, Universitas Islam Indonesia, Yogyakarta, Indonesia
}

Original Article

\begin{tabular}{l}
\hline ART ICLE INFO \\
\hline Keywords: \\
Diabetes mellitus, \\
total cholesterol levels, \\
triglyceride levels, \\
insulin monotherapy, \\
combination therapy of \\
insulin and metformin
\end{tabular}

*Corresponding author: pritamurani158@gmail.com

DOI: 10.20885/JKKI.Vol10.Iss1.art3 History:

Received: September 12, 2017

Accepted: February 4, 2019

Online: April 30, 2019

Copyright @2019 Authors. This is an open access article distributed under the terms of the Creative Commons Attribution-NonCommercial $\quad 4.0$ International Licence (http:// creativecommons.org/licences/ by-nc/4.0/).

\section{ABSTRACT}

Backround: Diabetes mellitus (DM) is a degenerative disease predicted by WHO to increase in Indonesia from 8.4 million in 2000 to around 21.3 million in 2030. Diabetes mellitus is closely related to dyslipidemia which can increase the risk of coronary artery disease (CAD). Current DM treatment is using oral hypoglycemic drugs, insulin, or a combination of both. Many previous studies have not examined the effect of these therapies on lipid profiles, specifically total cholesterol and triglyceride levels.

Objective: To determine the differences in changes in total cholesterol and triglyceride levels between the use of insulin monotherapy and combination therapy of insulin and metformin in patients with type II diabetes mellitus in Sleman Yogyakarta Hospital from January 2010 toJune 2012.

Methods: This study was an observational analytic study using a retrospective cohort study method with samples $(n=64)$. Samples were taken by non-probability consecutive sampling, carried out in DM patients inpatient or outpatient at Sleman Yogyakarta Hospital for the period of January 2010 - June 2012. The samples were divided into two groups, insulin monotherapy group and insulin and metformin combination therapy group. The data taken was the total cholesterol and the first triglyceride level, then the second total cholesterol and triglyceride data were made after four months of getting therapy.

Result: Analysis of statistical data using the Mann Whitney test for changes in total cholesterol levels in the two treatment groups showed $\mathrm{p}=0.166$, whereas for changes in triglyceride levels in the two treatment groups it was found that $\mathrm{p}=0.840$.

Conclusion: There were no significant differences in changes in total cholesterol and triglyceride levels between the two treatment groups.

Latar Belakang: Diabetes melitus (DM) merupakan penyakit degeneratif yang diprediksi WHO akan meningkat di Indonesia dari 8,4 juta pada tahun 2000 menjadi sekitar 21,3 juta pada tahun 2030. Diabetes melitus erat hubungannya dengan dislipidemia yang dapat meningkatkan risiko terkena coronary artery disease (CAD) atau penyakit arteri koroner. Pengobatan DM saat ini adalah menggunakan obat hipoglikemik oral, insulin, maupun kombinasi keduanya. Penelitian terdahulu belum banyak yang 
meneliti mengenai pengaruh terapi-terapi tersebut terhadap profil lipid, khususnya kadar kolesterol total dan trigliserid.

Tujuan Penelitian: Untuk mengetahui perbedaan perubahan kadar kolesterol total dan trigliserid antara pemakaian monoterapi insulin dengan terapi kombinasi insulin dan metformin pada pasien diabetes melitus tipe II di RSUD Sleman Yogyakarta Periode Januari 2010 - Juni 2012.

Metode: Penelitian ini merupakan penelitian observasional analitik dengan menggunakan metode penelitian kohort retrospektif dengan sampel $(n=64)$. Sampel diambil dengan cara nonprobability consecutive sampling, dilakukan pada pasien DM rawat inap atau rawat jalan di RSUD Sleman Yogyakarta periode Januari 2010 - Juni 2012. Sampel dibagi menjadi dua kelompok, yaitu kelompok monoterapi insulin dan kelompok terapi kombinasi insulin dan metformin. Data yang diambil adalah kadar kolesterol total dan trigliserid pertama, selanjutnya diambil data kolesterol total dan trigliserid kedua setelah 4 bulan mendapatkan terapi.

Hasil: Analisis data statistik menggunakan uji Mann Withney untuk perubahan kadar kolesterol total pada kedua kelompok terapi didapatkan hasil $p=0,166$, sedangkan untuk perubahan kadar trigliserid pada kedua kelompok terapi didapatkan hasil $p=0,840$.

Kesimpulan: Tidak terdapat perbedaan bermakna perubahan kadar kolesterol total dan trigliserid antar kedua kelompok terapi.

\section{INTRODUCTION}

Diabetes mellitus (DM) is one of the degenerative diseases with increasing prevalence in the future to cause a significant threat to global health in the 21st century. ${ }^{1}$ Numerous epidemiological studies indicate a tendency to increase the incidence and prevalence of DM in various parts of the world. The World Health Organization (WHO) predicts that there is a significant increase in the number of people with diabetes in Indonesia from 8.4 million in 2000 to around 21.3 million in $2030 .^{2}$

A recent study conducted by the $\mathrm{MOH}$ Research and Development in December 2008 showed that the national prevalence for impaired glucose tolerance (IGT) was $10.25 \%$ and for diabetes as much as $5.7 \%$. Those consisted of $1.5 \%$ of patients who had been diagnosed with previous DM and the remaining $4.2 \%$ were only known to have DM when the study was conducted. The prevalence rate was taken from the results of the entire province, with West Kalimantan and North Maluku provinces occupy the highest DM prevalence rank. ${ }^{3}$

In general, there are two types of DM, type I and type II DM. In Indonesia, the prevalence of people with type I DM is unknown, although it is assumed to be very rare. This might be because most diagnoses of type I DM in Indonesia are often late. Therefore, the patient has died from complications before being diagnosed. In contrast, the prevalence of type II DM patients is more than type I DM, which covers $90 \%$ of all diabetic populations. ${ }^{3}$

DM is closely related to the condition of dyslipidemia, which is called diabetic dyslipidemia. In The Framingham Heart Study, it was stated that the prevalence of men and women with DM is $13.3 \%$ and $24 \%$ respectively, had an increased plasma total cholesterol levels compared to men and women without DM, as much as $9 \%$ and $15 \%$. The prevalence of lowdensity lipoprotein (LDL) cholesterol in men $(9 \%)$ and women $(15 \%)$ with DM did not show a significant difference compared to men and women without DM as many as $11 \%$ in men and $16 \%$ in women. Furthermore, the prevalence of plasma triglyceride levels in individuals with DM (as many as 19\% in men and $17 \%$ in women) is higher than for individuals without DM (as many as $9 \%$ in men and $8 \%$ in women). ${ }^{4}$

Similar patterns of changes in levels of lipid profile in DM patients were also obtained from the UK Prospective Diabetes Study (UKPDS) study. In this study, total cholesterol levels in individuals with DM with individual control groups were no different. LDL cholesterol levels in women with type $2 \mathrm{DM}$ are higher than in women without diabetes. Plasma triglyceride levels in type $2 \mathrm{DM}$ patients generally increase, while High-Density Lipoprotein (HDL) cholesterol levels decrease in both women and men compared to the control group without diabetes. ${ }^{4}$

There is evidence of an association between the condition of dyslipidemia and the increased 
risk of cardiovascular disease, which can cause death in type II DM patients. Several other studies have shown an association between LDL cholesterol levels and coronary artery disease (CAD) or coronary artery disease. ${ }^{5}$

Currently, several widely used types of therapy in DM patients to control blood glucose levels are oral hypoglycemic drugs, insulin, or a combination of both. There are some previous studies which not only examining the effects of these DM therapies on blood glucose levels but also examined the impact of these therapies on total cholesterol and triglyceride levels. One investigated the effects of metformin on glucose levels lipid profiles, and arterial blood pressure in patients with type II diabetes mellitus. This study shows that administration of metformin can reduce serum triglyceride levels and LDL cholesterol, and increase HDL cholesterol levels. ${ }^{6}$

Some studiesexamine differences in efficacy and safety in the use of different approaches. They assessed insulin monotherapy, combination insulin therapy with metformin, and combination insulin therapy with troglitazone by looking at differences in changes in HbA1c levels and levels of lipid profiles, before and after an intervention. This study shows that the administration of insulin monotherapy can reduce serum triglyceride levels and total cholesterol. While giving combination therapy with metformin showed the results of increased serum triglyceride levels and total cholesterol. ${ }^{7}$

Research on the relationship between different approaches of DM therapies with changes in levels of lipid profiles, especially total cholesterol and triglycerides, has not been widely carried out, hence new research is required. This is one reason why the author took the study titled "Differences in Changes in Total Cholesterol Levels and Triglycerides between Use of Insulin Monotherapy and Combination Therapy of Insulin and Metformin in Type II Diabetes Mellitus Patients".

This research was conducted at Sleman Yogyakarta Hospital due to its abundant data of the DM patients. Besides, in Sleman Yogyakarta Hospital, no one has ever done a study on the differences in changes in total cholesterol and triglyceride levels between the use of insulin monotherapy and combination therapy of insulin and metformin in DM patients, especially type 2. Therefore, research is needed in this specific location.

\section{METHODS}

This study is a two-group numerical comparative analytic study using the retrospective cohort study. The researchers studied the relationship between independent variables; insulin monotherapy and combination therapy of insulin and metformin and dependent variables; total cholesterol levels and triglyceride levels. The aim was to determine whether there are differences in changes in total cholesterol and triglyceride levels between the use of insulin monotherapy and combination therapy of insulin and metformin in type II DM patients in Sleman Yogyakarta Hospital in the period January 2010 - June 2012. The target population of this study was all DM patients in Indonesia. The studied population in this study were patients who were diagnosed with type II DM who were treated and registered in the medical record at Sleman Yogyakarta Hospital for the period of January 2010 - June 2012.

The research subjects used were those that met the inclusion and exclusion criteria. Inclusion criteria include:

a.Hospitalised and outpatient diagnosed with type II DM in medical records found in Sleman Yogyakarta Hospital fromJanuary 2010 to June 2012.

b.Patients who get insulin therapy only.

c. Patients who received a combination insulin therapy with metformin.

d.Patients had examined lipid profile levels twice in a minimum of 4 months and received treatment according to the criteria points $b$ and $\mathrm{c}$ between the two examinations.

Exclusion criteria include patients who have concomitant diseases such as chronic renal failure and nephrotic syndrome.

The research subjects used in this study were 32 subjects in the insulin monotherapy group 
and 32 subjects in the combination therapy group insulin and metformin, so that the total research subjects used were 64 subjects.

This study uses secondary data, the medical record of patients diagnosed with DM at Sleman Yogyakarta Hospital from January 2010 to June 2012.

The data is processed using the SPSS application with a paired t-test, and the results are presented in a table form which consists of differences in changes in the levels of the lipid profile of each treatment group and $p$ values for normally distributed data which is tested by the Kolmogorov test-Smirnov. For data that are generally not distributed is processed using the application of SPSS with the Wilcoxon test and the results will also be presented in table form.

\section{RESULTS \\ Data Characteristics}

Sixty four samples were obtained, consisting of 32 samples in the insulin monotherapy group and 32 samples in the combination therapy group of insulin and metformin. Characteristic data includes age, patient's sex, first total cholesterol level, first triglyceride level, and current blood sugar level (table 1). From the p-value obtained, it can be concluded that there is no significant differences in terms of age, sex, blood glucose levels, the first total cholesterol level and the first triglyceride level in the two treatment groups.

Table 1. Characteristics of Sample Data

\begin{tabular}{lccc}
\hline \multicolumn{1}{c}{ Characteristics } & $\begin{array}{c}\text { Insulin } \\
\text { monotherapy }\end{array}$ & $\begin{array}{c}\text { Insulin and Metformin } \\
\text { Combination }\end{array}$ & p \\
\hline Patient number & 32 & 32 & \\
Age & $56,34 \pm 8,88$ & $57,50 \pm 7,47$ & $0,575^{*}$ \\
Gender & & & \\
$\quad$ Male/Female (\%) & $8 / 24$ & $9 / 23$ & $0,779^{* *}$ \\
& $(25 / 75)$ & $228,1 / 71,9)$ & \\
First total cholesterol (mg/dL) & $250,97 \pm 82,64$ & $199,66 \pm 140,62$ & $0,372^{* *}$ \\
First triglyceride (mg/dL) & $248,97 \pm 273,95$ & $283,4 \pm 93,07$ & $0,175^{* *}$ \\
Blood glucose (mg/dL) & $288,88 \pm 67,37$ & &
\end{tabular}

Comparison of Total Cholesterol Levels and First and Second Triglycerides in Each Therapy Group

Comparison of the first and second cholesterol and triglyceride levels in both groups is presented in Tables 2 and 3.

There were significant differences in the first and second total cholesterol levels in the two treatment groups, both in the insulin monotherapy group ( $p=0.043)$, and the insulin and metformin combination therapy group ( $p$ $=0.004$ ) and on average total cholesterol levels decreased in both groups of therapy.

Table 2. Differences in First and Second Total Cholesterol Levels

\begin{tabular}{lccc}
\hline & $\begin{array}{c}\text { First total } \\
\text { cholesterol (mg/dL) }\end{array}$ & $\begin{array}{c}\text { Second total } \\
\text { cholesterol (mg/dL) }\end{array}$ & P \\
\hline Insulin Monotherapy group & $250,97 \pm 82,64$ & $226,59 \pm 42,32$ & $0,043^{* *}$ \\
Insulin and Metformin combination group & $224,47 \pm 49,94$ & $202,75 \pm 38,74$ & $0,004^{*}$ \\
\hline
\end{tabular}

The data above shows the mean \pm SD, ${ }^{*}$ uses paired t-test and ${ }^{* *}$ using the Wilcoxon test 
Table 3. Differences in First and Second Triglyceride Levels

\begin{tabular}{lccc}
\hline & $\begin{array}{c}\text { First triglyceride } \\
\text { (mg/dL) }\end{array}$ & $\begin{array}{c}\text { Second triglyceride } \\
\text { (mg/dL) }\end{array}$ & P \\
\hline Insulin Monotherapy group & $248,97 \pm 273,95$ & $191,09 \pm 91,26$ & $0,112^{* *}$ \\
Insulin and Metformin combination group & $199,66 \pm 140,62$ & $171,56 \pm 83,76$ & $0,274^{* *}$ \\
\hline
\end{tabular}

The data above shows the mean \pm SD, ${ }^{*}$ uses paired t-test and ${ }^{* *}$ using the Wilcoxon test

There were no significant differences in the levels of first and second triglycerides in the two treatment groups, both insulin monotherapy $(p=0.286)$ and the combination insulin and metformin therapy groups $(\mathrm{p}=0.331)$, and mean levels triglycerides decreased in both groups.

\section{Tablet evaluation}

For changes in total cholesterol levels in the two treatment groups, the data analysis used the Mann Whitney test, and the results obtained $\mathrm{p}=$ 0.166 which means that there were no significant differences between the two groups of therapy. Whereas for changes in triglyceride levels in the two treatment groups, data analysis also used the Mann Whitney test, and the results were $p=0.840$, meaning there were no significant differences between the two groups of therapy.

\section{DISCUSSION}

Currently, the standard therapy for DM ranging from using insulin, oral hypoglycemic drug therapy alone, a combination of oral hypoglycemic drugs with one another, and a combination of insulin with oral hypoglycemic drugs. These therapies are intended to keep blood sugar levels back to normal and wellcontrolled diabetes mellitus.

In terms of insulin mechanism, the target of insulin is not only the metabolism of carbohydrates but also lipids and proteins. Insulin may influence lipid metabolism by increasing glucose transport into adipose tissue cells, activating enzymes that catalyse the formation of fatty acids from glucose derivatives and increasing the entry of fatty acids from the blood into adipose tissue cells. Besides, this hormone is inhibiting lipolysis (fat breakdown) which resulted in a decrease in fatty acid expenditure. ${ }^{8}$
Insulin also increases the transcription of lipoprotein lipase in capillary endothelium. Therefore, the state of hypertriglyceridemia and hypercholesterolemia often occurs in patients with diabetes mellitus who do not get therapy. ${ }^{9}$ Insulin induces and activates lipoprotein lipase to hydrolyse triglycerides from lipoproteins, inhibit intracellular lipases, and provide glycerol phosphate so that esterification of fatty acids is supplied through lipoprotein transport. ${ }^{10}$

Reinforced by the previous study, it is firmly stated that insulin monotherapy can decrease the total cholesterol and triglyceride levels. ${ }^{7}$ By that, our results showed that insulin monotherapy could result in a decrease in total cholesterol and triglyceride levels.

The combination of metformin and insulin is better than insulin monotherapy. The result of metformin's actions includes a decrease in gluconeogenesis in the liver and kidneys and a slowdown in glucose absorption from the gastrointestinal tract by increasing conversion of glucose to lactate by enterocytes. In addition to that, direct stimulation of glycolysis in tissues with increased glucose clearance from blood, and decreased plasma glucagon levels have also been observed. ${ }^{10}$ Suyono et al. (2011) stated several other effects of metformin, including a decrease in blood glucose levels by improving glucose transport to muscle cells stimulated by insulin, a stable body weight, and an improvement in lipid profiles. $^{2}$ Besides, metformin can affect blood lipid profile levels in terms of reducing levels of total cholesterol and serum triglycerides. ${ }^{11}$ Therefore a combination of insulin and metformin can provide better results.

Riddle (2008) also states that combination insulin and metformin therapy can provide better control of blood glucose levels. Other benefits 
are a smaller risk of hypoglycemia and a slight increase in body weight, compared to insulin monotherapy alone. Therefore, combination therapy has become a standard method for treating DM patients type II with normal glycemic targets. ${ }^{12}$

In line with those previous study, our results showed that the combination of insulin and metformin provides better results. It is proven by the results of a decrease in total cholesterol and triglyceride levels after using combination insulin and metformin therapy.

However, our obtained results are not by the study conducted by Strowig, et al. (2002) which stated that combination therapy of insulin and metformin increased total cholesterol and serum triglyceride levels. This result might occur due to the differences in research subjects and also confounding variables that cannot be excluded from the study, such as diet, physical activity or exercise, patient compliance, etc. ${ }^{7}$

Our study found about $34 \%$ of the samples in the insulin monotherapy group, and $9 \%$ of the samples in the combination therapy group insulin and metformin who were also received simvastatin therapy is a dyslipidemia drug. It works by inhibiting the enzyme HMG CoA Reductase, an enzyme that plays a role in cholesterol synthesis so that the formation of hepatic cholesterol decreases. This also increases the LDL receptors on the liver surface so that LDL cholesterol is pulled towards the liver and will decrease LDL cholesterol. ${ }^{13}$ This simvastatin administration can be stated as the weakness of this study because it has the potential to influence the final results. Also, other drugs that can affect the result include Fenofibrate, Bezafibrate, Gemfibrozil, Nicotinic Acid, Probucol, etc., which are alternative therapies for anti-dyslipidemia in addition to simvastatin. ${ }^{14}$

The goal of DM therapy is to control blood glucose levels and to prevent complications. There are several criteria for controlling diabetes mellitus related to the level of lipid profiles, especially total cholesterol and triglycerides. The criteria for the controlled total cholesterol levels if the levels are $<200 \mathrm{mg} / \mathrm{dL}$, moderate if the levels are 200 - $239 \mathrm{mg} / \mathrm{dL}$, and poor if $\geq 240$ $\mathrm{mg} / \mathrm{dL}$. Whereas for triglycerides, declared good control if the level is $<150 \mathrm{mg} / \mathrm{dL}$, moderate if the level is $150-199 \mathrm{mg} / \mathrm{dL}$, and bad if the level is $\geq 200 \mathrm{mg} / \mathrm{dL}^{3}$

In this study, the second cholesterol level averaged around $226.59 \mathrm{mg} / \mathrm{dL}$ in the insulin monotherapy group and $199.63 \mathrm{mg} / \mathrm{dL}$ in the combination therapy group of insulin and metformin. By looking at these results, it can be stated that the total cholesterol control is classified as moderate in insulin monotherapy and the control of total cholesterol is classified as good in the administration of combination therapy of insulin and metformin. Furthermore, the average second triglyceride level was 191.09 $\mathrm{mg} / \mathrm{dL}$ in the insulin monotherapy group and $171.56 \mathrm{mg} / \mathrm{dL}$ in the combination therapy group of insulin and metformin. Then it can be inferred that triglyceride control is classified as moderate in both groups of therapy.

Nevertheless, that administration of insulin monotherapy and combination therapy of insulin and metformin alone is not very helpful in controlling DM disease, seen from total cholesterol and triglyceride levels. Therefore, it requires the additional treatment to overcome the condition of dyslipidemia which often accompanies DM disease. Treatment of dyslipidemia, among others, can be in the form of diet regulation, risk factors control, administration of drugs, and manage the causes of secondary diseases that underlie the occurrence of dyslipidemia. ${ }^{14}$

\section{CONCLUSION}

There were no significant differences in changes in total cholesterol and triglyceride levels between the insulin monotherapy group and the combination therapy group of insulin and metformin.

\section{ACKNOWLEDGMENT}

None declare

\section{Conflict of interest}

None declare. 


\section{REFERENCES}

1. Sudoyo AW, Setiyohadi B, Alwi I, Setiati S, Al E. Ilmu penyakit dalam. V (3). Jakarta: Interna; 2009.

2. Perkumpulan Endokrinologi Indonesia (PERKENI). Konsensus pengendalian dan pencegahan diabetes mellitus tipe 2 di Indonesia 2011. Jakarta; 2011.

3. Suyono S, Waspadji SW, Soegondo S, Soewondo $\mathrm{P}$, et al. Penatalaksanaan diabetes melitus terpadu. Jakarta: Balai Penerbit FK UI; 2011.

4. Mooradian AD. Dyslipidemia in type 2 diabetes mellitus. Nature Clinical Practice Endocrinology \& Metabolism. 2009;5:150-9.

5. Krauss MR. Lipids and lipoproteins in patients with type 2 diabetes. Diabetes Care Journal. 2004;27(6):1496-504.

6. Mourao-Junior CA, Sá JR, Guedes OMS, Dib SA. Effects of metformin on the glycemic control, lipid profile, and arterial blood pressure of type 2 diabetic patients with metabolic syndrome already on insulin. Brazillian Journal of Medical and Biological Research. 2006;39(4):489-94.

7. Strowig SM, Avilés-Santa ML, Raskin P. Comparison of insulin monotherapy and combination therapy with insulin and metformin or insulin and troglitazone in type 2 diabetes. Diabetes Care. 2002;25(10):1691-8.

8. Sherwood L. Human physiology : From cells to system. 2nd ed. Nella Yesdelita, editor. Jakarta: EGC; 2001.

9. Brunton LL, Parker KL, Blumenthal KD, Buxton I. Goodman \& Gilman manual farmakologi dan terapi. July M, editor. Jakarta: EGC; 2008.

10. Katzung BG. Basic \& Clinical Pharmacology. 10th ed. Jakarta: EGC; 2007.

11. Tjokoprawiro A. Diabetes melitus klasifikasi, diagnosis, dan terapi. Jakarta: PT. Gramedia Pustaka Utama; 2001.

12. Riddle MC. Combined therapy with insulin plus oral agents: Is there any advantage? Diabetes Care. 2008;31(Supplement 2):125-30.

13. Sinorita H. Diabetes melitus dan dislipidemia. In: Seminar Nasional 2007 Clinical Updates. Bagian Ilmu Penyakit Dalam
Fakultas Kedokteran UGM/RSUP Sardjito; 2007. p. 29-36.

14. Syarif A, Esuningtyas A, Setiyawati A, Muchtar A. Farmakologi dan terapi. 5th ed. Jakarta: Balai Penerbit FKUI; 2009. 